\title{
The Strict Criminal Liability in Iran's Criminal Legal System
}

\author{
Seyyed Mahmoud Mir-Khalilii ${ }^{1} \&$ Abuzar Salarifar ${ }^{1}$ \\ ${ }^{1}$ Department of Criminal Law, Qom Branch, Islamic Azad University, Qom, Iran \\ Correspondence: Abuzar Salarifar, Department of Criminal Law, qom Branch, Islamic Azad University, qom, \\ Iran. E-mail: Abuzar.salarifar@gmail.com
}

$\begin{array}{lc}\text { Received: July 12, } 2016 & \text { Accepted: August 18, } 2016 \quad \text { Online Published: September 29, } 2016 \\ \text { doi:10.5539/jpl.v9n8p24 } & \text { URL: http://dx.doi.org/10.5539/jpl.v9n8p24 }\end{array}$

\begin{abstract}
The strict criminal liability is one of the institutions which has been accepted and expanded its dimensions in countries, including England, since $19^{\text {th }}$ century. Although, criminal intent or fault is the most important elements of every offenses, but, due to some reasons, such as expediency, necessity, benefit, increasing prevention index, the mens rea element of offense, fully or partially, is sometimes removed or presumed. In Iran's criminal legal system, this legal institution has not been considered formally and explicitly by the legislator, but recently, Iranian legal experts, given some existing necessities, try to put some offenses into the category of the strict criminal liability. In fact, some offencesin criminal legal system, namely traffic offences, bounced cheque, injuries resulted from medical operations and some environmental offences, can be placed under the title of the strict criminal liability. Despite many problems to which the acceptance and development of the strict criminal liability may be faced, It seems, in many cases, this institution can solve the problems related to difficulties of proof and ascertainment of the criminal intent beforecourts. Also, today, Iranian judicial courts don't take into account the mens rea practically and presume itin many cases.
\end{abstract}

Keywords: fault, strict liability, non-faultliability, strict liability offence, absolute liability

\section{Introduction}

A traditional analysis conducted about offense by legal experts offers that an act is recognized as anoffense if it has three elements.In jurists' pinion, the threefold elements of offense, namely legal basis, actusreus, mens rea, have general characteristics and their existence in all offenses is necessary. (Goldouzian, 2004, p.72 \& Aodeh, 2011, p.120)

In modern criminal law, this principle has beenproperly established that actusreus does not cause liability unless mens rea as one of offense pillars accompanies it. (Hasani, 2014, p.7)

Today, criminal intent or mens rea as one of self-evident elements of offensein light of some indicativeness has been considered and accepted by law-makers. The acceptance of mens rea in offense's body and the criminal liability causes the emergence of a concept of blameworthiness (criminal value). In other words, criminal value of an act refers to its capability of being blamed or amount of reprimand which can be imposed ona committer through determining and carrying out punishment. The capability of blameworthiness depends somewhat on the norm or value is violated, the damage is caused or the dangersare created. In other hand, it depends on the amount of fault and guilty mind which perpetrator demonstrates. Thus, a wrongful act which is conducted intentionally is more blamable rather than an act committed by mistake or carelessness and negligence. Accordingly, despite the amount of loss and damage created by an offense, the blameworthiness of an act depends on other factors and elements. A child's conductviolating a criminal norm is not as blamable as an adult's, even if the results of their acts are the same. (Golami, 2014, p.31) The basis of this viewpoint is the principle of individual independence or acceptance of capability of selecting and controlling a wrongful act by human factor.

According to general rules, however, the element of fault or mens rea (capability of being blamed), as one of the obvious and fundamental terms and preconditions, is considered for imposing punishment and criminal liability, but there is a group of offences (of course, in some legal systems like England's criminal legal system, they cannot be categorized under the title of exceptional group, because, according to the England's jurists, the half of the country's been offenses supposed in form of the strict liability.) which exceptionally they don't need the fault element and proof of blameworthinesscapability. Even, they don't require fault in its special meaning of criminal 
fault.

In this type of offenses, it is likely that defendant, under no circumstances, has no criminal intent and does not deserve to be blamed. This issuewhich when such offenses were supposed as a basis of a liability in customary criminal systems is not exactly known. But it is obvious that fromthe $18^{\text {th }}$ and the $19^{\text {th }}$ centuries which the Industrial Revolution occurred, the strict liability concept was developed too. Of course, the main domain of such offensesis public health, environment, and generally public welfare. Jurists believe that the tendency of law-makers for developing the concept of offenses with the strict liability has been increased during the $20^{\text {th }}$ century.Given the society's needs and necessities and also complicities of social relations and regulation of such relations, this liability has gained great importance. (Clarkson, 2011, p.21).

Notwithstanding, it should be accepted that nowadays the strict criminal liability or no-fault liability is one of the legal institutions which can be considered in some legal fields. And initially, it should be confirmed by Iranian legislator to provide a practical ground for it, which albeit, it required a deep and proficient debate and analysis over the regarding issue. And also, by thorough examination, the legislator must take a clear position to importance and place of mens rea, which hereby such decisions can be reflected in jurisprudence. From other hand, the categorizing offenses based on mens rea in cases which possibility and necessity of acceptance of the strict liability exists, can help to be provided a practical ground for such liability to be operational.

\section{Conceptual Framework of the Strict Criminal Liability}

The strict criminal liability or no-fault liability which has beeninitially considered by jurists in Common Law countries particularly in England's legal system; today it has been accepted remarkably in many countries. In recent years, this concept has been experienced a considerable growth of research works in Iran's scientific and academic circles. And recently some researches have been conducted in this field.

\subsection{Concept of the Strict Criminal Liability}

As the strict criminal liability is a importing concept, so, there have been expressed many equivalents for it in Persian legal literature, including absolute criminal liability, no-fault offences, no-fault criminal liability, strict liability offences, strict liability, material liability and ..., which they are sometimes applied for each other's place without paying attention to the burden of their meaning. Regarding the concept of the strict criminal liability, there are many challenges in Common Law countries. Despite the conflict existing in Common Lawcountries and other countries accepted theconcept of the strict criminal liability, the problem to which we face and also we will deal with it in following, is the Persian translation of "the strict criminal liability", which has been translated in different forms in Iran. At first, we deal with the nature of concept of the strict criminal liability and different ideas existing about it, and then, we speak of true equivalent which should be applied for this institution in Iran's legal system.

The strict liability, in fact, is a concept coming from blameworthiness of perpetrator. Although, there was little attention for mens rea in past and the liability was just created through focusing on actusreus. Thus, the most important element of an offence at that time was actusreus and the liability was created and punishment was imposed on perpetrator as soon as the actusreus was ascertained. But, after this stage of law history, particularly in religious communities, the criminal liability under religious trainings was separated from religious and objective nature, and established on ethical and justice principles. (Mir-Saeedi, 2007, p.13) In fact, mens rea is the capability of blameworthiness which today it is regarded as an important condition in determining individuals' penalty, and even asubstantial criterion in establishing punishment ${ }^{1}$. Common Law Jurists have expressed different interpretation and opinions about the nature and concept of the strict liability. (Gardner, 2007, P.232 \& Husak.cit 1995, pp: 199-223).

Notwithstanding, the strict criminal liability or no-fault liability, from conceptual and interpretative viewpoint, bears many, and occasionally, different verities. The study of such interpretations shows that the legists have made many attempts to find a reasonable and equitable level of the strict criminal liability.

\subsection{Typology of the Strict Criminal Liability}

Given that the strict liability has different types in which mens rea, fully or partially, is sometimes removed or ignored, thus, such types are described extensively hereunder.

\footnotetext{
${ }^{1}$. Researches which have been conducted about England' criminal legal system shows that fault as the basic of criminal liability was not recognized until the end of the $12^{\text {th }}$ century.
} 


\subsubsection{Full Removal of Mens Rea}

In an occasion where mens rea is removed fully, not only this element has been ignored by law-maker andit can be said that it bearsno importance for legislator and the assumption is lack of mens rea, but in practice, perpetrator may have no guilty mind. In such occasions, the substantial elements of mens rea, including criminal intent, fault element and awareness don't exist.An important point which may cast the mind is that how it is possible an individual committing an offense with no mens rea receives the same punishment which an individual doing it with all elements of criminal intent. Is such approach in compliance with justice? This issue is one of the main serious ambiguities of the strict liability theory. Though, there should be an effect of blameworthiness in an act which it deserves a penalty, with the result, this approach has not been accepted as a comprehensive approach even in England's criminal law. One of resolutions which may be offered to answer such ambiguity is to differentiate the amount of liability between an individual committing an offense with fault and an individual doing it with no fault. In other words, in an assumption omitted fault, we can punish both above mentioned individuals, but we can consider fault element as an aggravating factor, in a way, a person having fault deserves heavier punishment. The problem raised in such occasion is that judicial authorities must make all attempts to establish fault, not as a conditions of imposing criminal liability, but as aggravating factor. So, this has the same difficulties which ascertainment of fault as a term of criminal liability was previously caused and thus thisdoes not have any compatibility with the basis of the strict criminal liability and not seems reasonable.

Nevertheless, in regulatory offences or some other offenses, the legislator may consider no fault or malice intent in determining liability. And this can be interpreted by two reasons. First, based on theory of risk; the nature of such offenses calls for the ignoring the mens rea, and second, the sanction of these offenses are not too heavy, so the removal of mens rea can be justified.

\subsubsection{Partial Removal of Mens Rea}

In this type of the strict liability, a part of mens rea is ignored and only one part of the mens rea isrequired to be established by judicial authorities. Thus, as just the judicial authorities ascertain one of parts of the mens rea or even lower degree of the mens rea, the punishment can be imposed on committer. (Simester, 2005, p. 1-9)So, we can imagine some assumptions for this type of liability. In one assumption, if officials establish one part of all elements of mens rea, it is sufficient that the liability is created. In second, it is required that a lower degree of mens rea to be proven, including negligence. (Abdollahi, 2014, pp: 93-115).

For more explanation of above assumptions, we can exemplify following examples. For instance, a person carries a suitcase containing heroine, but he thinks it contains opium. Given that keeping and carrying opium often bear less punishment than heroine and also, the person has no awareness of real contents of the suitcase, so he deserves only the punishment specified for opium. But, regarding to existence of a part of mens rea, it can be said that such person has liability for keeping and carrying heroine and so the punishment of this liability will be imposed on him.In other assumption required to be substantiated a lower degree of the mens rea, we can give above mentioned example again. Suppose, the person carrying the suitcase has no exact awareness of contents of the suitcase being heroine, but there are some indications (for example, the person suggested the carriage of the suitcase has criminal records of narcotic drugs) which can imply the existence of drugs in the suitcase, but the indications are not too persuasive. In this situation, although the person has no awareness of the contents of the suitcase, but his negligence as a lower degree of the mens rea is sufficient to establish his liability. And this is a type of the strict liability.

Some jurists have divided two above assumptions into two new categories as absolute liability and non-absolute liability. Absolute liability refers to those offenses which there is no need of mens rea in respect of all elements of actusreus, on the contrary, in non-absolute liability, the existence of mens rea in regard of at least one elements of actusreus is necessary the liability to be established. (Simons, 1997, p: 1079)

\subsubsection{Presumingmens Rea}

Given the fault assumption is contrary to principle of innocent and also, in the legal system of Iran, is opposed to legal principle of "Dara $\bar{a}$ ", thus it is applied in a limited range of cases and its domain is confined to only certain offences, which they should not be expanded. But the strict liability or no-fault liability in which the fault can be rejected is one of the most appropriate assumptions which can be accepted in a legal system and certain cases. Because, in comparison to other assumptions of removal or denial of mens rea, it bears less challenges and has more conformity with justice. Particularly, regarding to this fact thatthe ethical prepositions and the blameworthiness element have merged in the criminal legal systems, the offense commitment without mens rea is not acceptable and is considered as contrary to justice. 


\subsubsection{The Analysis of Above Assumption and Their Applications}

In response to this question that which above mentioned assumptions should be considered in a legislation system, it can be said that it is extensively depended on an offense for which the strict liability will be applied. In other words, as discussed previously, in assumption which all parts of the mens rea have been removed or ignored, whether committer has fault or not, the punishment, in any way, will be imposed on him. Thus there is no opportunity for perpetrator to prove his faultlessness. As such liability system usually raises great criticisms among legalexperts, so it can be used in a limited range of cases. One of domains which the mens rea can be removed fully is traffic offenses which it is absolutely free from establishment of criminal intent.Like the example givenin respect of this field in previous parts. Two other assumptions involved in removal or denial of part of mens rea along with an assumption which mens rea exists have more compatibility with justice and legal reasonability, which can be applied in different issues. It seems this system of liability can be applicable in those domains which the criminalization developed for the express purpose of public health and protection of environment. Becausethe values violated and assaulted by commission of offenses are very vital and important, and also, as Iranian community has not socially and culturally developed so enough that it can be possible to burden heavy penalties on some offenses with nature of public effects, including environmental crimes, thus the legislator can increase the risk of commission of such crimes by establishingthe strict liability belonging to those types which some parts of mens rea have been removed, and defining some punishments for themwith proportionate $^{2}$ and light nature. This approach can increase preemptive and preventive factor too.

\section{Fundamentals of Criminal Strict Liability}

After studying the concept and history of strict liability, we deal with the fundamentals and principles governing it. As the strict criminal liability is a newly-emerged legal institution in Iran, so, at first, it is necessary to be studied its theoretical and practical fundamentals, in a way that the main challengeswhich such liability may be faced in its judicial procedure can be determined. The important point in this filed is that the Iranian legislator both can apply this legal institution in some offenses and prevent its possible problems and challenges by using the experiences of countries with the Common Law legal system. The main basics governing the strict criminal liability are pointed out in below:

\subsection{Theory of Risk}

One of the most important basics of the strict liability both in civil and criminal issues is the theory of risk. With emergence of the Industrial Revolution, the fundamentals of liability were evolved and deficiencies of fault-based liability revealed, as a result, legal experts suggested the theory of risk. Based on this theory, there is no need to inspect perpetrator's mind for ascertaining mens rea in order to establish (criminal or civil) liability. If an individual causes injuries or losses to someone or community by his conducts, he will be liable for compensation of the losses with respect to civil liability and taking punishment in regard to criminal liability. In other words, everyone creating dangerous and risky environment for people, should be liable for consequences of his conducts.

According to this theory, the criterion of the liability is the causality relationshipbetween committer's conduct and damage attributable to the committer. In this legal system, every person causing damage to another through his conducts will be liable, aside from his conducts are legitimate or not. In fact, all persons are liable for compensating risks resulted from his conducts. Based on the principle which every person benefiting from a business, they should assume the responsibilities for its losses, it seems such assumption of liability is not based on fault or mens rea, but, it is founded on a risk which committer creates through dangerous environment, from one hand, and also the liability is rooted in benefit which committer gains from such circumstances, from other hand. The supporters of the theory of risk believe this theory has the preventive and intimidating value and with the result of its implementation, distressing incidents and damages are reducedin social and economic relations. Because, if everyone knows that he is liable for consequences of his conducts, he will inevitably adopt a preventive and precautionary approach toward his conducts. (Hosseini-Nejad, 1991, p: 21)

\subsection{The Principle of Necessity and Expediency}

In all historical periods, necessity and expediency have constituted the basis and foundation of the criminal law. In other words, even in the most important issues of the criminal law, including criminalization and penalization, the signs of necessities and expediencies are obvious. From such viewpoint, offenses are divided into natural

\footnotetext{
${ }^{2}$. The proportionate punishment refers to those penalties that they can be named as society-based or typically security and preventive measures. In field of environment, proportionate punishments can include as to plant trees, to clean coasts from rubbishes, to cultivate seedlings and trees, to clean off forests and deserts, to breed hunting animals, to feed hunting animals, to train environmental affair to others.
} 
offenses and artificial or contractual offenses. In contractual offenses, the principal and substantial basis for criminalization is founded on public interests and also social necessities. The criminal system as a social system tries to make regulations based on categorizing public and social needs and interests, and presents appropriate responses to these needs and interests.

Thus, it is obvious that observing expediency and necessities is one of the important basics of the no-fault liability or the strict liability. In a way that the criminal law can, in many cases and in the framework of these principles, ignore the traditional ethical considerations, of course with regarding expedient dimensions and taking fundamental precautions. Anyway, it seems that the strict liability can be justified in framework of expediency and necessity and judicial authorities can ignore fault element in certain and necessary occasions.

\subsection{The Principle of Utilitarianism}

The utilitarianism is divided under the broad category of the teleologism. In respect of the relationship between utilitarianism and the strict criminal liability and whether the theory of utilitarianism can serve as the basic of thestrict criminal liability or not, it can be said that as one of the main purposes of the strict criminal liability is protection of public interest, in a way that almost all fields in which the strict criminal liability is applied or suggested to be used are relatively connected with public interests, so it seems this theory can be regarded as one of the important and acceptable fundamentals of the strict criminal liability. The fields of environment, public hygiene, public health, traffic affairs are the most obvious examples in which the criminal law has used the strict liability as the basic of liability. In such fields, public interests are very tangible and it shows that the strict criminal liability is designed with the purpose of public interests protection.

Although, from viewpoint of ethics and moral thoughts, the strict criminal liability is not acceptable due to removal of blameworthiness criterion and moral rules and imposing a type of liability without regarding fault element, butit is justifiable by considering great benefits which it provides for society for public interests. In other words, as Jeremy Bentham said, a duty like justice can be meant where it moves on the way of prosperity of the most people of society. Likewise, although the strict criminal liability poses some problems to committer of a wrongful damaging act, but as the public interests have more degree of importance than the blameworthiness rules, so the public interests are prioritized rather than other factors of liability.

\subsection{The Preventive and Preemptive Principle}

Prevention and preemption of offenses are one of the main justifications suggested for the strict liability in criminal affairs. Suggesting and establishing an institution under the title of the strict criminal liability or no-fault liability, like other measures, includingnew criminalization and penalization which are developed for increasing the protection and control index of offense commitment, is justifiable. In other words, the risk and expenses of offense commitment will be increased by establishing the strict criminal liability and those offenses on which such liability is imposedhave much hindrance.

\subsection{Socialism Instead of Individualism}

Based on individualistic thoughts, the main purpose of legal rules is to hold individuals in respect and importance and maximally to provide their needs, rights and freedom in society.According to these ideas, what really exists in world is human beings, and society is constituted of humans, thus the main goal of law is to protect humans' interests. Consequently, society will be served as a tool through which individuals can exercise their rights. (Katouzian, 2005, p.44).

\subsection{Principle of Fault Assumption}

One of the reasons and justifications resulted in the acceptance of the strict criminal liability is the difficulty of mens reato be established. In other words, as mens rea is an internal factor which is ascertained difficultly, and for this reason, many courts impose punishment on perpetrators based only on actusreus elements and without regarding mens rea. Due to difficult ascertainment of mens rea, public order may not be secured properly and this will provide good circumstances through which wrong doers can escape from punishment and criminal liability.This problem can lead to abuse from legal gaps and particularly in those cases that an important value may be violated; the damage will be difficult to be compensated. As establishment of fault, in some occasions, is difficult and it may be led to injustice, so the assumption is made on existence of fault and judicial authorities are exempted from ascertaining fault to develop the criminal liability. (Abdollahi, 2014, p. 265).

\section{Territory of the Criminal Strict Liability}

This issue that thestrict criminal liability should be applied for which offenses or the territory of such liability has been expanded to what extent has made many debates. From one hand, jurists don't often determine the 
domain of the strict criminal liability explicitly. In other words, they don't assert that the no-fault liability covers which offenses. This causes diversity of opinions in jurisprudence and in some countries, like England where there are many offenses with the strict liability, courts take caution to apply such liability and usually base the liability upon fault, in a way that establishment ofindividual's fault is necessary in constitution of liability.

In occasions which the jurist does not find any sign or indication implying whether an offense needs mens rea or not, it should not be interpreted that the purpose of the legislator was to impose the no-fault liability or the strict criminal liability. But, in such occasions, the court will try, according to principles governing the interpretation of criminal rules, to define the issue. In most of cases, this analysis leads to imposition of the fault-based liability, not the strict criminal liability. (Clarkson, 2011, p.217).

\subsection{Disciplinary Offenses}

One of the fields in which the strict liability is used is disciplinary offenses. As legal experts define, a disciplinary offense refers to a wrongful act which it does not really affect a moral issue and usually has a light punishment. Such offenses are often defined for public welfare or improving social relations.Offenses, like wrongful acts in field of food stuffs, cosmetics and hygienic material sale, technical regulations on work and safety of working environment, and traffic offenses, are appropriate examples of disciplinary offenses (Eliot, 2008, p.83). In fact, the nature and subject of disciplinary offenses compared to the traditionaloffenses are mostly welfare-related and prudential. Indeed, the purpose of the law-maker in such offenses is to protect public interests and usually introduce them vis-à-vis the real and important offenses. The great volume of the disciplinary offenses results in disregard of mens rea or other indicators of blameworthiness. If proving the criminal intent was recognized necessary, for example in all cases involved in car stop at all zones of absolutely prohibited parking, it would causeto be wasted lot of time during trails. (Clarkson, 2011, p.217) Thus, it can be said that the establishment of capability of blameworthinessin the disciplinary offensesis not beneficial and leads to waste of time and expenses. Also,as the competent authorities to take proceeding for such offenses arenon-judicial authorities who often inflict punishment without having any judicial experiences and specialization, and regarding to the importance of proceeding speed, the ascertainment of fault in such offenses cannot be necessary and they can be considered as offenses with the strict liability. (John, 2007, p. 153)

\subsection{Offenses with Light Punishments}

The strictcriminal liability is often established for offenses having relatively light punishment. In legal experts' opinion, the more extensive a punishment is determined for an offense, the less likely the strict liability which is imposed on that offense. Of course, this matter that the strict criminal liability is imposed only on not-severe offenses and heavy punishments are always accompanied with fault-based liability is not guaranteed and there may be some assumptions which the strict liability stands along with heavy penalty and vice versa. (Eliot,2008,p.87) In those cases for which pecuniary punishment or lighter penalty is used, it seems that the application of the strict liability will be better, because, otherwise, it will cause to be wasted a lot of time and expenses of courts for establishing mens rea. Particularly, in spite of acceptance of the strict liability, in this method, we can, on the assumption of mens rea existence, put the burden of proof of faultlessness on perpetrator.

\subsection{Offenses with Substantial Value}

In some cases, it is likely that the value which the law-maker protects it through criminalization belong to those important values which need broad and strong protection by the legislator. In such occasions, it is possible that the law-maker to use the strict liability. In environmental offenses or offenses related to public health and hygiene, for example, although all offenses violating rules connected to public welfare or order and consequently the strict liability should be applied for them, but it seems the connection with public affairs is not the sole reason to impose the strict liability and it can be said that because of protecting the substantial value being on the risk of violation the law-maker applies the strict criminal liability for these fields.

For this reason, in the caseB which has been brought before the court against the prosecutor, the judge Lord Nicoles said "the nature of an offense and the badness or evil which must be prevented from being committed is regarded as one of the important factor for imposing the strict liability." (Abdollahi, 2014, p.33).

In those occasions which an important social issue posed on the risk of violation, in order to persuade convicts to avoid from offense commission, it may be possible to use the strict liability. Albeit, in all cases which an important value violated, there does not need the strict liability to be used. For instance, murder andrape, both belong to those offenses through which an important value is violated, but it does not trigger that those take the title of offenses with the strict liability.Such offenses, in respect of subject, may interfere with disciplinary offenses, but the major difference of these offenses with disciplinary offenses may be in penalties which can be 
imposedon convicts. Offenses violating a substantial value usually have more extensive punishments. (Eliot, 2008, p.85)

\subsection{Offenses Having Vulnerable Victims}

One of the fields that the strict liability can be used is those occasions which victims of regarding offenses mostly are potentially weak or vulnerable. In this case, the strict liability can be considered as apreventive action for protecting these people. Such liability can be used in those cases in which the most part of people have fewer options to decide and participate. For example, in case of buying foods and drinks or breathing air where there is not clean air. Or, if victimsare affected by offenses committed by children who are abused by adults, court is more interested in imposing the strict liability. In fact, the purpose of law in such cases is to protect children against abuse and humiliation. (Clarkson, 2011, p.21) Those other people who can be potentially abused are women and the elders. Thus, harassment against and insult to women and elders can be considered as those cases for which the strict liability can be applied. Other category of vulnerable people is workers who continuingly are at the risk of abuse of employees. By expanding the strict liability to working fields, the law can protect workers from such offenses.

\subsection{Offenses Committed by Others}

The strict liability can also be applied in those offenses which committed by others. In other words, in assumption which a person is punished due to another's wrongful act there does not require mens rea to be ascertained. The criminal liability for employee or director of a newspaper created through violation of regulations or arrangements by works or writers can be regarded as one of examples for liability resulted from other's act. (Janipoor \& Abassi, 2013, p.30).

\subsection{Offenses Related to Legal Persons}

One of cases which are often emphasized that the strict liability or no-fault liability can be applied for is the criminal liability of legal persons, especially companies. legal experts believe that as companies have complicated structure, so if the criminal liability of companies or their legal representatives are subject tomensreaor capability of blameworthiness, it may be led to inefficiency of regulations and escape of individuals from liability. Particularly, in such persons, the mens reacannot be truly ascertained. Given the complicated structure, the large and relatively complex companies can easily escape from liability and punishment, and this is one of serious obstacles to bring them under prosecution. In fact, establishment of the criminal liability of an individual working in a company is a difficult task and the only way which the law can be truly implemented is to use the strict liability. Some companies operate in a range of fields which they have potentially much social risks and provide for them considerable economic power and domination that if the legislator sets more stringent criterion to establish their criminal liability is not unjust. (Clarkson, 2011, p.22)

\section{The Strict Liability in Iran's Criminal Law}

As some legal experts assert, there is no explicit assertion about the strict liability in Iran's criminal legal system. In other words, although some occasions can be existed that based on a conjecture the jurist decides whether mens rea is required in respect of an offense or not, but it cannot be indicated that such offenses are regarded as offenses with the strict liability. Thus, the rule is that the offenses are intentional and even in unintentional cases offenses need the regulations' assertion or a persuasive conjecture. So, the strict liability, in more fitting way, require the assertion of law or a reliable evidence indicating to a rule of law. (Shahcheraq, 2011, p.10).

\subsection{Assumption of Awareness of Typically Fatal Act in Murder and Intentional Offenses}

One of the evident examples which the legislator points explicitly to the existence of awareness assumption is note 1 of the article 290 from the Islamic Criminal Law, enacted in 2013, which the law-maker presumes the existence of awareness and put the burden of proving the lack of awareness on the shoulder of perpetrator. Such cases which the existence of awareness as a part of mens rea is presumed can be interpreted as one of instances for the strict liability.

\subsection{Offense of Drawing a Bounced Cheque}

One of offenses which almost all Iranian legal experts believe the strict liability is imposed on is the offense of bounced cheque. (Abdollahi, 2014, p.103) Although some jurists opposed to such belief and asserted that the offense of bounced cheque is not placed under coverage of the strict liability. (Shahcheraq, 2011, p.10). In sum, the offense of bounced cheque in Iran's criminal legal system is recognized as an offense with the strict liability and the only occasion which this offense is not usually accompanied with no-fault liability and required mens rea is when the cheque is drawn from a blocked account. Albeit, it has been suggested that the offense of drawing 
unpaid cheque from a blocked account is also regarded as an offense with the strict criminal liability and only a defense of removal of liability, as describedabove, is maintained for convict. ${ }^{3}$

\subsection{Medical Incidents and Operations}

Currently some legists believe the Islamic Criminal Law enacted in 2013 has recognized the medical incidents and operations as offenses with the strict criminal liability. The article 495 of the mentioned law says: "If a doctor in his treatments causes damage or physical injury, he will be responsible for compensation, unless his action can be justified by medical regulations or technical arrangements or he has obtained prior acquittal and not also committed a fault. If acquittal obtained from patient due to immaturity or insanity is not valid or because of unconsciousness is not valid, the acquittal will be obtained from patient's guardian."According to above article, if doctor's actions lead to injuries to patient, he will be liable and must compensate. The only way that he can escape from liability is to prove he observe all scientific and technical arrangements and also does not commit any neglect or fault in his task. Albeit, such interpretation will be right if we consider compensation as a punishment in Iran's criminal law system, not as an institution with nature of civil liability. (Janipoor \& Abassi, 2013, p.48).

\subsection{Disciplinary Offenses or Breaches}

Offenses related to breaches domain are another group of offenses on which the strict liability can be imposed. Although they carry the title of breach, but as described before their main and substantial nature is an offense, so in Iran's criminal law system, they can be regarded as offenses with the strict liability. The traffic offenses are the most obvious example of such offenses. In Iran's criminal law system, the strict liability or no-fault liability governs on traffic offenses. Of trafficoffenses, currently, the administrative and police mechanisms are more used rather than criminal law arrangements. Notwithstanding, as such offenses don't require any mens rea or fault, the liability imposed on committer is the criminal strict liability.

Some other fields in which legists believe the strict liability is used include as followed:

Bandits and infringement of public security (article 281 of Islamic Criminal Law, 2013), article 1 of the Act for Prohibition of Use of Tools Applied for Receipt of Satellite Waves, (1994), article of 56 from the Act of Punishment of Armed Forces (2003), article 42 of the Act of protection and exploitation of forests and pastures (1977). (Abdollahi, 2014, p.105)

\section{Conclusion}

The strict liability or no-fault liability which has been initially entered into civil law, it was gradually penetrated into criminal law, particularly it was gained considerable attention in England's criminal law system and then expanded to other countries. Due to great theoretical and practical challenges which such liability carries in field of mens rea, so the element of mens rea can be removed fully or partially or it is presumed. In Iran's criminal law system, such liability can be observed in disciplinary offenses or in some public offenses. Given all analysisconducted in respect of existence or non-existence of the strict criminal liability in Iran's criminal liability, the main issue is that the Iranian law-maker does not asserted explicitly the removal of mens rea element, however, in some occasions, it has asserted the presumption of some parts of mens rea. Another issue deserved to be considered more seriously is that as the institution of strict liability is an importing concept and it has not been yet profited from a matured legal literature and even Iranian courts are not fully aware of the regarding concept, however in some last years, a lot of good researches have carried out and even are doing regarding to the strict liability. It seems, in those fields being necessary, like environmental offenses or public health and hygiene-related offenses, the Iranian law-maker must recognize the strict liability or no-fault liability. It causes the ground for entrance of the strict liability to the criminal law system to be prepared gradually and in those cases which there are justifiable reasons for accepting the strict liability it can be applied.

\section{References}

\footnotetext{
3. In a judgment made by one of the branches of Tehran's court of appeal, the judges concisely inferred and regarded the offense of drawing unpaid cheque from a blocked account as a fault-based offense which it is required mens rea and placed other forms of the bounced cheque offense under the title of the strict liability. They reason that just because the blockage of the account cannot be concluded as the awareness of the drawer. Because there are many cases which bank blocks a current account due to it was kept inactive for a long time, while the owner of the account is uninformed of such blockage. In following, the judges exculpated the convict from the offense of drawing unpaid cheque from a blocked accountaccompanied with awareness referred to article 10 of the Cheque Law enacted in 1993, and instead invoked to article 7 of the same law and sentenced the convict to the offense of drawing bounced cheque. As mentioned above, however the judge concluded that the perpetrator has not have any criminal intent and drawn the cheque without awareness, but they did not clear him and sentenced him to drawing a bounced cheque. It reveals that other forms of drawing unpaid cheque don't require mens rea.
} 
Abdollahi, E. (2014). The No-Fault Criminal Liability in the Criminal Legal Systems of Iran and England (3rd ed.). Khorsandi Publication, Tehran.

Aodeh, A. (2011). The Comparative Study of Islamic Criminal Law and Customary Law, translated by Hasan Farhoudi (Vol. 1, 1st ed.). Yadavaran Publication, Tehran.

Ardabili, M. (2013). The General Criminal Law (Vol 1, 31st ed.). Mizan Publication, Tehran.

Ashouri, M. (2007). Criminal Procedural Law (Vol. 2, 8th ed.). SAMT Publication, Tehran.

Bariklou, A. (2010). A Sight on the General Criminal Law (written statements of Mohammad Baheri) (3rd ed.). Majd Publication, Tehran.

Clarkson, C. (2011). Analysis of Basics of General Criminal Law, translated by Hossein Mir-Mohammad Sadeqi (1st ed.). Jungle Publication, Tehran.

Eliot, C. (2008). The Criminal Law, translated by Ava Vahed-Noori (1st ed.). Mizan Publication, Tehran.

Elliot, C., \& Quinn, F. (2000). Criminal Law, Pearson Education, Limited, London: Third edition.

Gardner, J. (2007). Answering for Crime Responsibility and Liability in The Criminal Law, XFORD and PORTLAND, Oregon.

Goldouzian, I. (2004). Necessities of General Criminal Law (9th ed.). Mizan Publication, Tehran.

Golriz, A. (2008). The Strict Criminal Liability (emphasized on Iran's Legal System), MA Student Thesis in Azad University, Branch of Qom.

Hasani, M. (2014). The General Theory on Criminal Intent, translated by Seyyed Ali Abbas NiyaeeZare (1st ed.). Mizan Publication, Tehran.

Hosseini-Nejad, H. (1991). The Civil Liability (1st ed.). Tehran, publication of Jihad-e-Daneshgahi of University of Beheshti.

Katouzian, N. (1997). Civil Law, Obligations out of Contract (Vol. 1). Publication of University of Tehran.

Katouzian, N. (2005). Liability Resulted from Defect of Production (2nd ed.). Publication of University of Tehran.

Katouzian, N. (2006). The Philosophy of Law (Vol. 1, 3rd ed.). Holding Company of Publication, Tehran.

Kenneth, W. S. (1997). When is Strict Criminal Liability Just. Journal of Criminal Law and Criminology, 87.

Lanipour, M. (2013). MoradAbbasi, The Study of the Strict Liability from Criminal Law and the ShiatFiq Viewpoint, on Emphasis of Doctor's Liability. Fiq and Islamic Law journal, 3(6).

Lefew, V. R. (2011). Mens Rea in The US's Criminal Legal System, translated by Fatemeh Mousavi Khoshdel (1st ed.). Mizan Publication.

Mir-Saeedi, S. (2007). Criminal Liability, Territory and Elements (Vol. 1, 2nd ed.). Mizan Publication, Tehran.

Rasa, M. (1996). the Civil Liability, translated by Mohammad Ashtari (1st ed.). Tehran, Hoqouqdan Publication.

Saki, M. (2014). The General Criminal Law, Criminal liability (Vol 2, 2nd ed.). Jungle Publication, Tehran.

Sanei, P. (2003). The General Criminal Law (1st ed.). Tarh-e-No Publication, Tehran.

Shahcheraq, S. (2011). The Study of The Strict Criminal Liability in Iran's Law, A Glance on Common Law Legal System. Legal journal of Dadgostari, (78).

Shams Natari, M. (2002). The Principle of Innocent and Cases in Which Escape from its Arrangement in Iran's Criminal Law. journal of High Education Complex, (14).

Simester, A. P. (2005). Appraising Strict Liability (1st ed.). Oxford,Oxford University.

\section{Copyrights}

Copyright for this article is retained by the author(s), with first publication rights granted to the journal.

This is an open-access article distributed under the terms and conditions of the Creative Commons Attribution license (http://creativecommons.org/licenses/by/4.0/). 